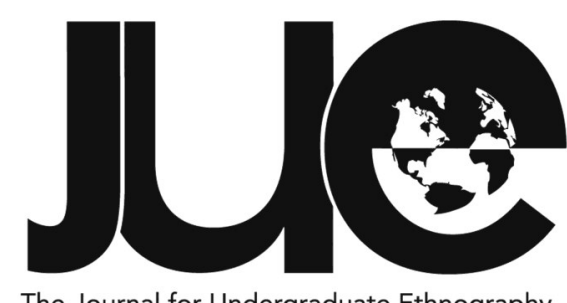

\title{
Epistemologies of Resistance: Knowledge in the Peruvian Amazon
}

\section{Lorena Reinert}

Messiah College, lorenareinert@gmail.com

\section{ABSTRACT}

Epistemologies of resistance are knowledge frameworks that challenge oppressive structures and the ideologies that sustain them. In this paper, I analyze three weeks of ethnographic fieldwork among the Asháninka of the Peruvian Amazon to demonstrate the ways in which the epistemologies that I encountered challenge oppressive structures and their underlying ideologies. My findings consider the use of social and environmental context as epistemic indicators. I contrast these context-dependent epistemologies with the context-independent epistemologies that dominate contemporary "Western" thought, where the goal is to separate knowledge from context. I then consider how, as hybrid epistemologies that have emerged out of interaction and exchange in a globalized world, indigenous knowledge frameworks resist the notion of a binary difference between indigenous and "Western" itself. These epistemologies of resistance critique the double binds created and sustained through the colonial model. 


\section{pistemology as Resistance}

Epistemology is the study of how we know what we know. It refers to the explanations and justifications that ground our knowledge, or our reasons for believing what we believe. These epistemologies can be stabilizing if they reinforce the existing social order, or disruptive if they call that order into question. José Medina (2012) defines epistemic resistance as "the use of our epistemic resources and abilities to undermine and change oppressive normative structures and the complacent cognitiveaffective functioning that sustains those structures" (3). Disruptive epistemologies expose the fault lines that underlie the ideologies of oppressive systems, calling those systems into question.

Indigenous ways of knowing constitute epistemologies of resistance. These are not "pure" forms of knowledge that lie beyond the influence of "Western" modernity, but hybrid ways of thinking and being that have developed in response to conditions of domination in the globalized world (Bhabha 1994; García Canclini 1995). Ramón Grosfoguel (2011) describes these syncretic epistemologies as "hybrid, transcultural forms of knowledge" and refers to them as "forms of resistance" (24). In the colonial context specifically, indigenous knowledge frameworks reveal epistemic hierarchies that give different weight to different ways of knowing. By pointing to histories of colonization and marginalization, these epistemologies shed light on global conditions of domination and call into question existing standards for what constitutes legitimate thought.

Of course, indigenous epistemologies have meaning and value in their own right, not just as acts of resistance. They did not come into being when Europeans arrived on the scene, and they are not defined solely in relation to colonialism. Still, indigenous epistemologiesjust like non-indigenous epistemologies-are the result of historical processes involving interactions, exchanges, and encounters with other people and ways of life. Even before colonialism, they were not "pure" forms of knowledge, but hybrid ways of knowing that came into being through relations of contact and exchange.

In this paper, I analyze three weeks of ethnographic fieldwork that explored epistemology among the Asháninka of the Rio Ene region in the Peruvian Amazon. My findings consider the use of social and environmental context as epistemic indicators. I contrast these context-dependent epistemologies with the context-independent epistemologies that often dominate contemporary "Western" thought, where the goal is to separate knowledge from context. Finally, I consider how, as hybrid epistemologies that have emerged out of interaction and exchange, indigenous knowledge frameworks challenge the binary distinction between indigenous and "Western" itself. I end with a discussion of two cases of hybridity that I encountered among the Asháninka-changing social roles and the use of human rights discourse-which contribute to epistemic resistance by challenging the double binds of the colonial tradition.

\section{Indigenous Knowledge as an Extractable Resource}

Past research on indigenous ways of knowing has focused on specific spheres of knowledge seen as central to indigenous life. One such sphere, Traditional Ecological Knowledge (TEK), considers the ever-evolving knowledge indigenous people hold of the land they inhabit. TEK has become particularly valuable in light of the contemporary environmental crisis and is now a key consideration in global conversations regarding natural resource management (Mishra 1998), biodiversity (Gadgil, Berkes, and Folke 1993), and sustainable agriculture (Sahai 1996). Indigenous knowledge has also been studied for its potential to contribute to medicinal practices (Orozco and Poonamallee 
2014), and an entire legal field has developed to protect indigenous knowledge from "biopiracy" - the theft of indigenous knowledge by multinational pharmaceutical companies and other corporate stakeholders (Norchi 2000; Barsh 2001; Chowdhury 2004).

These considerations of indigenous knowledge recognize its value and potential to inform the way we approach problems on a global scale. But they also separate indigenous knowledge from the local contexts within which it has developed and held significance (Simpson 2004; Wohling 2009). Indigenous knowledge is treated as yet another extractable resource, valuable for use in very different contexts than those in which it arose. Furthermore, this research conceives of knowledge primarily as a set of facts related to ecology and medicine. But knowledge also includes more fundamental questions related to how we see the world. Carothers, Moritz, and Zarger (2014) highlight the importance of asking deeper ethnographic questions here: "What is knowledge? What is knowing? ... How do local people conceptualize knowledge? ... How do we best construct formal models of representation, and how do we represent not knowing?" (42). These studies move beyond an understanding of indigenous knowledge as factual information independent of context, highlighting instead the idea of knowledge as a particular way of orienting towards the world within a given context.

More recently, authors have aimed to better engage the notion of indigenous knowledge as a particular orientation towards the world. Waziyatawin Angela Wilson (2004), for example, writes that indigenous knowledge is holistic and tied to different spheres, like ethics, health, education, and in particular the land, from which it cannot be separated. Knowledge arises out of experiences with people, places, and contexts, and that knowledge is fundamentally relational. It both shapes and is shaped by the people we interact with and the places we inhabit. Wilson advocates for the recovery of traditional indigenous knowledge in order to regain "the ways of being that allowed our peoples to live a spiritually balanced, sustainable existence within our ancient homelands for thousands of years" (359). Indigenous knowledge here is not just knowledge of information, but knowledge of how to live well within a particular context. The idea of buen vivir, or sustainable well-being, is inseparable from knowledge.

Much of this literature considers indigenous knowledge to be a matter of tradition that must be safeguarded and preserved. Traditional knowledge is seen as key to indigenous identity and culture, and as with language and folklore, anthropologists have felt pressure to learn and record it so it can be preserved before it is lost forever. This approach recognizes the value of indigenous ideas and underscores the many ways that we can learn from indigenous thought. But at the same time, it fails to consider the colonial context and new, changing notions of indigenous identity and knowledge. Culture and knowledge are viewed as islands, pure entities untouched by interaction and exchange. But indigenous cultures and epistemologies are just as much the result of ongoing processes of adaptation, transformation, and hybridity as other cultures and epistemic frameworks. Cultural change is a genuine concern for many indigenous people, but framing change as a matter of either preservation or extinction fails to take into account the way in which cultures adapt and express agency through processes of change.

\section{Agency and Double Binds}

In a world shaped by colonial structures, double bind situations-where all available options serve to reinforce one's own oppression-are found in abundance. Making sense of agency in these situations is a major ethnographic predicament. Franz Fanon (1967) considers this dilemma in his examination of the racial frameworks that have arisen out of colonial encounters. Among the characteristics that have become associated with blackness are instinct, irrational impulse, and primal sensuality. Fanon writes that this traps him in the double bind of a binary framework. If he acts rationally, he becomes "less black" and inadequately represents his people and culture. But if he acts irrationally, he reinforces the idea that black people are irrational. No matter what choice he makes, he loses.

Building on the work of Fanon, Achille Mbembe (2017) examines related questions of 
agency and constraint by mapping out a genealogy of black reason. He outlines the historical construction of black identity and rationality from the trans-Atlantic slave trade to the contemporary world. Mbembe's historical lens reveals the process by which "black" has become a signifier for irrationality. At the same time, Mbembe indicates the many ways in which black people have resisted this domination by adopting new subjectivitieslearning to read and write, leading slave revolts, and initiating abolition movements-that express agency.

Like black identity, indigeneity has come into being as the irrational Other to "Western" rationality. The irrationality of indigenous peoples was codified through the creation of explicit categories that distinguished "civilized" Europeans from "savage" natives. Bartolomé de las Casas argued in 1552 that the natives of Latin America were human beings just like European colonists, and this led to the belief that the natives of the land had souls and could not be killed indiscriminately. But this concession of humanity was accompanied by an epistemic distinction between white Europeans and the native inhabitants of the lands they colonized. Europeans occupied the top of the epistemic ladder, while the "savage" inhabitants of the jungle, seen as lacking both written language and political organization, occupied the bottom (de Acosta [1590] 2002). A racial hierarchy became an epistemic one, with "Western" identity and thought designated as the pinnacle of rationality.

This epistemic hierarchy forms the historical backdrop against which indigenous ways of knowing are perceived. Given these conditions, painting indigenous epistemologies as legitimate forms of rationality means locating them within a framework in which the more rational they are, the less indigenous they become. But the alternative-claiming that the indigenous somehow oppose rationality or modernity-only serves to reinforce the dualistic framework created by colonialism in the first place. As Santiago Castro-Gómez (2015) argues, indigenous identity is located on the fringes of modernity and rationality, not outside of these. Its perspective is thus neither antimodern nor irrational. The critique indigeneity offers of coloniality is powerful precisely because it represents an experience of an alternative rationality, which de-centers the "Western" tradition from the position it has claimed at the forefront of rational thought.

\section{Methodology}

In August of 2018, I conducted three weeks of ethnographic fieldwork in the Rio Ene region of Peru, located in the province of Junín in the Central Amazon. Prior to that time, from August of 2017 to July of 2018, I had spent two semesters as an exchange student at the Pontificia Universidad Católica del Perú (PUCP) in the capital city of Lima. In February, during a break between semesters, I worked for several weeks as a volunteer on an organic farm in Junín. During my time there, I was introduced to Lourdes, the assistant director of development projects for the native communities in the district. She was a young, easy-going Asháninka woman who had grown up in a nearby native community. She became interested in my research, and we maintained contact during the months that followed after I returned to Lima. During that time, I completed the Institutional Review Board (IRB) process at Messiah College and received approval to conduct fieldwork in her community. When I returned to Junín in August, she brought me to her parents' house, where I stayed over the course of my fieldwork.

My fieldwork itself consisted primarily of participant observation, which I conducted at typical community events like church services, sports games, and political gatherings. I also conducted interviews, both unstructured and semi-structured, with people who had ties to the community. Some lived there permanently, while others had grown up in the community but lived in nearby towns. Still others lived in the capital city of Lima, approximately eight hours away by bus, and returned only occasionally to visit their families. Though most were native Asháninka, some were colonos, migrants from the Andean highlands who lived in neighboring villages or who had married Asháninka members of the community. Some older members of the community still spoke the native Asháninka language to one another, but the majority of Asháninka people were more comfortable speaking Spanish. Apart from a few basic phrases I learned in the Asháninka language, all my communication with 
Asháninka people took place in Spanish. Quotes from conversations and interviews are my own translations.

Because I had not arrived in the community through a formal program, the contributions I made were arranged informally, through conversations with the jefa (elected leader) and the family with whom I was staying. Most evenings during my fieldwork, I taught English, which the jefa had requested of me as a contribution to the community. Due to a national holiday, school was not in session during the first two weeks of my fieldwork. During that time, I held evening classes for both children and adults in the village's community center. At the beginning of my third and final week of fieldwork, school resumed, and I taught at the elementary school. There were around 15 students, ranging from first graders to sixth graders, in a single combined classroom.

Most mornings when school was not in session, I accompanied Lourdes' mother Angélica, with whom I was staying, to the cacao fields. The cacao harvest was in full swing when I arrived, and there was plenty for me to assist with-harvesting the ripe cacao pods from the plants where they hung, cutting them open and removing the seeds from inside, and moving the seeds into burlap sacks to take to the local cacao cooperative. In addition to this, I also helped with the cooking and cleaning, and I sometimes purchased food to contribute to meals.

Still, I often wondered how much I was contributing, and what constituted an equal exchange. My own positionality within the community was a constant question mark. My cooking abilities were less than ideal, so in that regard I often felt useless. During English classes, too, I found myself wondering what I had to offer. Several members of the community had told me that learning English was important to them for labor opportunities, tourism prospects, and higher education possibilities. But my presence in the community was short-term, and teaching in the elementary school meant that students were forgoing their usual curriculum during that time. Was that sustainable? Was my contribution genuine? My identity as a white, English-speaking American shaped the epistemic authority I was granted, and I was continually reminded of that during my time in the community.

\section{The Question of Why}

When I first began my fieldwork among the Asháninka, I found myself frequently asking the question, "Why?" Even when I did not use the word "why" specifically, I usually made an effort to probe for clarifying details when I received information that seemed confusing to me. It became my standard reaction when I did not understand the purpose or reason for something, which was a frequent occurrence. I assumed that if I knew why things were happening-if I could get an explanation for a given statement or situation-l would better understand what was going on around me, and I would have a better sense of how people thought about their own beliefs, actions, and values.

This approach soon proved ineffective as I began to realize that my requests for an explanation were typically ignored. In response to my queries, I often received the same information I had just been given, formulated in a slightly different way, or I would be given new details that had nothing to do with the question I had asked. When the Asháninka family I was living with told me one day that I should not remove the shells from the sacha inchi nuts they had recently harvested, even though we had spent most previous afternoons taking the shells off the nuts, my "why" query was met with the responses, "It's not good to take the shells off," and, "It would be better to work in the cacao fields today." Days later, someone mentioned the explanation I had been looking for-that this particular batch of nuts had contained a large amount of moisture, and that we had waited a few days to take the shells off because the process was much easier when they were dry. This kind of information was seldom communicated to me in response to my "why" queries.

Members of the community also seemed uninterested in finding explanations for my own actions, which must have seemed confusing to them the same way their actions sometimes seemed strange to me. I began to notice that "why" was not a question people frequently posed to one another. They rarely 
drew upon cause and effect explanations or universal reasoning to make sense of their beliefs and actions. If these explanations were not common justifications for people's beliefs and actions, I wondered, how were these legitimated? What made a belief true, or a person's knowledge justified?

\section{Person-related Epistemology}

Angélica, the mother of the family that I lived with in the community, often told stories about the self-help seminars she had attended. Sometimes medical professionals came to the community to talk about health and nutrition, and Angélica always made sure to attend these meetings. Other organizations occasionally offered workshops on conflict resolution or selfimprovement, and Angélica would go out of her way to participate in those, too. As a devout Seventh-day Adventist, she also took the opinions of religious leaders seriously. As often as several times a month, she traveled to the city an hour away to consult a well-known religious leader on issues that concerned her.

In each of these cases, Angélica justified the knowledge she received on the basis of the personal qualifications of the people who shared their expertise with her. In the context of health, she explained that the knowledge she gained was justified because the people who shared it were experts in the field of nutrition. The seminars she attended on conflict resolution and self-improvement were organized by professionals who had also studied and practiced the techniques they shared. Their knowledge was reliable because they were considered experts. In the same way, the advice she sought from Adventists was legitimate because of their role as religious leaders. Angélica used personal characteristics of the people who shared their knowledge with her to justify its legitimacy. Both their educational qualifications and their social position as a professional or religious leader were taken into account. These examples show that for Angélica, epistemology was fundamentally connected to people and their identities.

The Seventh-day Adventist church has been present in the Central Amazon since the arrival of the first missionaries in the 1920s (Rojas
Zolezzi 2014). In the community where I conducted fieldwork, Angélica was the only Asháninka person who regularly attended Adventist services. She was sometimes criticized by her children for her religiosity, and they refused to accompany her to weekly services and prayer meetings. In neighboring Asháninka communities, however, Adventism remains prevalent. Juan Carlos La Serna Salcedo (2010), writing to explain the growth of Adventism among the Asháninka, argues that adscription to Adventism may be viewed as a "test of civilization" in the context of a traditional belief system viewed by the surrounding society as "uncivilized" (21). In other words, joining a Christian church may offer Asháninka people epistemic credibility by providing them with what is perceived as a coherent belief system to replace their own "irrational" set of beliefs. Yet, as La Serna Salcedo indicates, indigenous Adventism is a syncretic tradition. The person-related epistemology modeled by Angélica, who used the social role of religious leaders to justify the knowledge they offered, indicates that this way of knowing is present in contemporary indigenous Adventism.

My own knowledge was frequently tied to my qualifications and social position as well. Aspects of my identity were made explicit when members of the community asked for my opinion. Often, family members would ask me for information or advice on topics related to health and nutrition. They cited my status as a "professional"-someone who has formally studied for a profession-as evidence for why my opinion was reliable, even though I had no formal qualifications that would legitimate my knowledge on topics in these fields.

My personal qualifications were also used as an indicator of my knowledge in the realm of education. On days I taught English at the elementary school in the community, the teacher often asked me to continue teaching the class even after I had finished my English lesson. Again, the word "professional" was used to describe me and to indicate that my knowledge was reliable. I was not formally qualified to teach, and there was no way to verify if the information I taught was true by detaching it from me as the knower and 
considering it independently of myself. My status as a university student from the United States granted me epistemic authority. I taught English, geography, and history, sometimes for over half of the school day. Had I not stopped and gone to take a seat, the teacher probably would have asked me to continue for the rest of the day.

Gender was also cited as an aspect of my identity that determined what knowledge I was qualified to share. In the home, most responsibilities fell upon women. They were responsible for cooking, cleaning, and caring for children. As a woman, I was expected to have knowledge pertaining to each of these things. When it came to cleaning and caring for children, I fulfilled these expectations. I knew how to wash my clothes by hand properly, and the adults of the community entrusted their children to me, particularly when they were busy or needed a break. But I did not know how to cook, and that was a serious problem.

Angélica's request one day was simple: "I won't be home until late, and there's not enough rice for everyone to eat. Can you cook more?" I told her yes. It's just rice, I thought. It can't be that hard. But I had spoken too soon. First, the matches were too tiny for my large hands, and my repeated attempts at lighting the stove were useless. Then, after Angélica's son came and lit the burner for me, I overestimated the amount of water to add to the rice. It cooked eventually, but it was soggy and inedible. When even the dogs refused to eat it, I carried it to the ditch where food waste went, dumped it all in, and covered it with banana leaves.

When Angélica and her husband came home, they scolded me and told me that it is essential for a señorita, a young lady, to know how to cook rice. Angélica remarked that my mother had failed to teach me one of the most important skills a señorita should have. As time went on, the problem grew. I often offered to help with the cooking, but Angélica soon realized that this would require her to take the time to explain what to do to me, which was not actually helpful at all. I did not have the knowledge that corresponded to my social role. That was a problem. These experiences brought to the forefront my own positionality in the community. Was this an equal exchange? Was I contributing enough? How did my own identity as a white, English-speaking American impact how I was perceived-and what I perceivedduring my time in the community?

The cooking situation repeated itself when Angélica's twelve-year-old granddaughter came to visit from the nearby town where she lived with her mother. She was chastised many times for not knowing how to do tasks like cook and wash clothes, seen as basic responsibilities for a girl her age. When Angélica asked her to make rice one day, she protested that she did not know how. Angélica's husband scolded her: "She doesn't know anything! She doesn't even know how to make rice. That's not okay. That's not how it should be. A señorita should know how to cook." Angélica stood up for her by responding, "She's just a girl! When I was her age, I didn't know either. I had to learn little by little."

At its core, the argument between Angélica and her husband revolved around the relationship between knowledge and social identity, and in particular what knowledge their granddaughter's identity should merit. This was characteristic of discussions about whether or not someone should be expected to know something and whether or not their knowledge should be considered legitimate. The heart of the debate lay in whether or not characteristics of the knower merited knowledge of the topic, not in consideration of the knowledge as an independent, stand-alone piece of information.

Characteristics of the knower were also used to disqualify that person's knowledge when it came to topics they were unlikely to be familiar with based on their social position. In these cases, the person's social identity was invoked as an explanation for why their knowledge was unreliable. I experienced this in the context of agriculture and in other situations where Asháninka people believed that my social role disqualified me from knowing something that their identity qualified them to know. Members of the community referred to my status as a professional to indicate that I lacked legitimate knowledge of cacao and other crops. Angélica told me straightforwardly while working in the cacao fields one day, "You're a professional. That's why you don't understand cacao." My 
educational background indicated that I lacked legitimate knowledge of the agricultural world.

On another occasion, a friend of Angélica's daughter shot a deer and sent meat home with everyone in the family. I told Angélica and her husband that there are deer where I'm from, too, and that my father and brother often go hunting. My own social identity as a North American "professional" undermined the legitimacy of my claim and aroused skepticism. Angélica's husband asked me what color deer were, and I responded that they were brown with white spots. He then asked me if they had antlers. I answered yes, then clarified that they do if they are male. He was shocked and exclaimed, "I thought you were trying to trick me! But I guess you're telling the truth." My own identity initially disqualified me from having legitimate knowledge of hunting. My reliability as a knower was only restored after I had correctly answered his questions. This tactic seemed to be used for all topics related to agriculture and ecology, sectors someone in my social position would likely know little about.

Person-related characteristics connected to the identity, experiences, and qualifications of individuals were key to establishing epistemic legitimacy among the Asháninka. Members of the community used these characteristics to both assert the legitimacy of someone's knowledge and to discount it. Knowledge was not considered on its own terms, as isolated information, but was instead evaluated on the basis of the identity of the knower. Personrelated epistemology thus formed the foundation of knowledge for the Asháninka.

\section{Place-related Epistemology}

On walks to and from the family's fields, about a half hour in each direction, Angélica often pointed out the plants that lined the path along the way. She would tell me their names in both Spanish and the native Asháninka language and explain how each one could be used to treat an illness. Occasionally, she collected the leaves from a plant and took them back to her house, where she would prepare a remedy for a friend or family member who she knew suffered from a certain ailment.

While most remedies involved drinking water that had been boiled with the leaves of a plant, herbal baths were another treatment option. Angélica recounted story after story of people with physical or psychological ailments who had taken herbal baths and then been cured of their suffering. When her aunt suffered a stroke that paralyzed her from the neck down not long after I arrived in the community, Angélica collected medicinal plants and took them to her aunt's house. She used them to give her aunt an herbal bath, which she hoped would improve her health. Angélica's actions demonstrate the importance of the environment as a source of knowledge for the Asháninka. The legitimacy of knowledge in the realm of medicine and health stemmed from ecological knowledge of plants and their uses. Environmental context was foundational to knowledge the same way that social context was.

The herbal bath for Angélica's aunt was intended to treat a physical ailment, but plants were used as a treatment for psychological and spiritual problems as well. For instance, Angélica's twelve-year-old granddaughter had been significantly impacted by an ongoing conflict between her parents that had caused them to separate the previous year. She was often irritable and would challenge her mother, grandmother, and other authority figures when instructed to do something. When Angélica's granddaughter left the indigenous community to return home to her mother's house after spending a week with her grandmother, Angélica brought along special herbs that she planned to use to bathe both her daughter and granddaughter upon reaching their house.

When they arrived, however, Angélica realized she had left the bag of herbs on the bus they had taken to reach the town where her daughter and granddaughter lived. She was distraught for several days. Their situation surely would have improved, she told me, if only she had been able to bathe them both with the herbs she had collected. This scenario, like the previous one with Angélica's aunt, indicates that the environment played an important role in knowledge for Angélica. Because she was familiar with the land she inhabited and the plants that grew there, she was able to treat both physical and psychological ailments. Having legitimate knowledge in the realm of 
health and medicine was dependent on her connection to the land. Context, in this case environmental, was inseparable from epistemology.

Changing cultural practices, though, have brought changes to this tie to the land. When Angélica pointed out plants to me on walks, she often added wistfully that her children no longer knew the names and uses of the plants that were so important to her and others in her generation. Younger generations preferred to take medicine when they were sick instead of using plants as remedies, and Angélica herself looked first to doctors and psychologists when something went wrong, using medicinal plants only to supplement the treatments they prescribed.

Others in the community echoed Angélica's concerns about changing relationships with the land. Many told stories of their grandparents and great-grandparents who used to go hunting and bring home game for the entire community to share. The community's current territory does not include forests, and even in nearby areas where there are forests, game is sparse. Changing environmental conditions like mining, deforestation, and climate change have meant that many past ways of life are no longer viable options for indigenous peoples. In the community where I conducted fieldwork, there is no longer any game to hunt or fish to fish for. But as an alternative, members of the community have formed a cacao cooperative, transitioning from a foraging society to an agricultural society. Current processes of change have added wage labor and "professional" occupations into the mix. These transformations have changed the Asháninka's relation to the land and, therefore, to knowledge. Even so, place continues to play a significant role in indigenous epistemology.

The Asháninka's relation to these changes is complex and multifaceted. Indigenous peoples are not passive bystanders in the face of environmental change, but neither are all indigenous people ardent environmentalists. The largest indigenous organization in the Rio Ene region where I conducted fieldwork is called La Central Asháninka del Río Ene (CARE) and legally represents 18 Asháninka communities and 33 annexes ("¿Quién es
CARE?" n.d.). CARE has successfully countered several proposed hydroelectric projects in the region and has obtained land titles for 18 native communities since it was established in 1993. Its most notable project is Kemito-Ene, a cacao cooperative with over 250 partners and both Organic and Fair Trade certifications. In 2019, CARE president Ángel Pedro Valerio, who started the cooperative in 2010, was awarded the United Nations Equator Prize for innovative, nature-based climate change solutions in recognition of Kemito-Ene's impact. He was invited to speak at the UN Climate Summit in New York City in September 2019, where he advocated for indigenous land rights and for greater protections against the encroachment of narcotraffickers on indigenous territory ("Líder indígena amenazado por narcotraficantes pidió garantías para su vida" 2019).

Still, not all indigenous people support conservation initiatives. Beth Conklin and Laura Graham (1995) use the term "ecologically noble savage" to refer to the image of indigenous peoples living in harmony with nature that dominates the contemporary imagination. Conklin and Graham write that "(in) the past two decades, the noble savage theme was recast with a distinctly ecological emphasis. Native peoples in general, and Native Americans in particular, came to be widely viewed as 'natural conservationists' who use environmental resources in ways that are nondestructive, sustainable, and mindful of effects on future generations" (697). This image is due in part to the joint rise of environmentalism and the indigenous rights movement at the end of the twentieth century, when both groups realized it was in their interest to incorporate the symbols and causes of the other (Pimenta 2007).

However, as Colchester and Gray (1997) indicate, conservation interests and indigenous autonomy do not always align. Many designated protected areas worldwide ban shifting agriculture and heavily restrict hunting, limiting food access for indigenous peoples whose presence in the area long precedes their establishment (Sylvester, García Segura, and Davidson-Hunt 2016). Conservation interests typically include habitat conservation and 
biodiversity preservation. In contrast, indigenous autonomy may favor economically viable options like mining, lumber, and monocrop agriculture-for example, cacao farming among the Asháninka. In addition, many creative, well-intentioned sustainability initiatives, such as the cacao cooperative located in the community where I conducted fieldwork, continue to fall short of meeting families' basic economic needs, including the ability to access quality food, education, and healthcare.

Indigenous peoples in favor of conservation initiatives may face the further challenge that their conception of nature differs from the conception that dominates the global environmental movement, which commonly advocates for ecological preservation and sustainable resource use. Nadasdy (1999) notes that the very terms "environmental" and "ecological" are products of a "Western" conception of the world. This is because "implicit in their use is the notion that human beings are separate and distinct from the rest of the world, and it is specifically the nonhuman part of the world which constitutes the 'environment"' (4). Yet there are those, among them many indigenous peoples, who make no rigid distinction between humans and the environment. They refer to themselves as "part of the land, part of the water" (McClellan 1987, 1). Eduardo Viveiros de Castro (2005) and Philippe Descola (2013) call attention to the presence of this conception of nature in Amazonia.

In order to gain the support of the environmental movement, indigenous peoples often are obligated to adopt the language, symbols, and views of nature that are internationally dominant. Conklin and Graham (1995) refer to this as "middle ground." This occurs when indigenous peoples frame their causes in terms that appeal to the concepts and values of the global environmental movement, even when these are not necessarily indicative of indigenous peoples' own worldviews and priorities. In the case of the Asháninka community where I conducted fieldwork, "middle ground" may generate pressure to represent their relationship with the land in terms of a romanticized connection to forests, even when priorities have shifted and the connection to the land looks different.

Sally Falk Moore (1987) asserts that cultural transformation involves processes of continuity as well as processes of change. Though cultural practices change over time, a cultural "structure" comprised of historically significant values and practices underlies those processes of change and shapes how they unfold (Leach 1961). Indigenous communities are navigating changing relationships with the land, but these processes of change are guided by collectively held practices and values. For the Asháninka, knowledge of plants and animals has changed from knowledge of hunting practices to knowledge of crops and potential diseases.

As younger generations become more and more connected to the capital city of Lima and to the world beyond Peru, the way in which indigenous peoples relate to the land, and the knowledge that underlies this connection, will continue to change. In the future, the Asháninka may no longer be able to identify medicinal plants, catch fish, or tend cacao fields. Still, place-based epistemology will likely continue to shape indigenous life. Perhaps it will be marked by a shift in focus from rural places to urban ones, or from agricultural contexts to industrial and service-sector ones. As social, cultural, and environmental changes occur, person- and place-related epistemologies look different. Yet, they continue to form the historical backdrop against which indigenous communities navigate the transitions they are experiencing.

\section{The Ethics of Knowing}

These research findings demonstrate that for the Asháninka, epistemology tends to be context-dependent. Social and environmental setting is inseparable from knowledge. In the contemporary world, however, contextindependent ways of knowing are dominant. Preference is given to knowledge that can be disconnected from the social and material conditions in which it is found. The scientific knowledge paradigm seeks to quantify and classify knowledge, providing universal explanations that hold true across contexts. The implication of this is that "the rich social and physical complexities of place are 
expressed as a set of numbers" (Nadasdy 1999, 11). Universal knowledge is privileged over particular, contextualized knowledge. The objects of scientific inquiry are also removed from their contexts and considered as independent entities. Plants are uprooted from the ground and placed on a black metal microscope where they are viewed as solitary specimen independent of larger landscapes. This scientific method is prioritized over an approach that studies plants within specific environmental contexts and sees their meaning as inherently tied to surrounding ecosystems.

The structure of the "Western" education system itself privileges context-independent epistemologies over context-dependent ways of knowing. Students are removed from the contexts of their ordinary lives and required to sit in confined spaces for hours on end. This physical separation between learners and their particular contexts is believed to facilitate learning, not to hinder it. Seana Mcgovern (2000) notes that "the establishment of school buildings in the Peruvian Amazon created indoor education, separating 'learning from the territory' and resulting in the 'resettlement of... dispersed clans to living in concentrated native communities"' (525). The dominant model of "Western" education fails to allow for learning in context, learning in nature, and learning while moving-all approaches that are central to indigenous learning. What matters is not personal experience in a particular context, but universal principles that can be abstracted from context. Separating knowledge from the conditions that give rise to it is seen as the goal.

The questions Carothers, Moritz, and Zarger (2014) raise become important in this context. "What is knowledge? What is knowing?" These queries force us to think about why we know and how we should know. The way in which we know is not neutral. Our epistemologies, or justifications for our knowledge, are indicative of our values. Justification based on principles tied to reason and argumentation-legitimacy that can be abstracted from context, made universal, and considered on its own termsindicates cultural values of universality and consistency. This ethical framework can be traced back to the liberal tradition that came out of the Enlightenment, when modern philosophers like Hobbes, Locke, and Kant sought to establish ethical models that would hold true across all contexts (Nowak 2017). These universal frameworks gave rise to "Western" epistemologies, which aim to distinguish knowledge from context.

If justifications for knowledge that can be abstracted and made universal are indicative of a cultural context that places value on these things, justifications based on contextualized, localized factors are indicative of a value system that places priority on particularity and context. This kind of epistemology regards knowledge as an interconnected act whose purpose is to relate us to the surrounding world. When knowledge is inseparable from people and places, acts of knowing and legitimating knowledge connect us to our social and environmental realities. Knowledge and truth do not abstract us from gender, ethnicity, geography, and language-the things that make us who we are-but instead more deeply connect us to these identities.

\section{Hybridity as Epistemic Resistance}

Even the distinction between contextdependent and context-independent epistemology, however, is connected to a history of oppression. The ethnic and epistemic hierarchies codified through colonial structures served to ensure that indigenous identity and knowledge were kept separate from "Western" identity and knowledge (de Acosta [1590] 2002). Binary classifications between indigenous context-dependent epistemology and "Western" context-independent epistemology merely reinforce this dichotomy, creating a double bind where indigenous peoples must choose between being rational and being indigenous.

Despite this, both indigenous and "Western" forms of knowledge and identity are hybrids, not "pure" forms of knowledge. Indigenous peoples are not restricted to using only contextdependent epistemologies. They are not incapable of invoking universal justifications or reasoning from first principles. Similarly, "Westerners" are not entirely unaware of the importance of context. They may look to experts, social cues, or environmental context as ways of justifying knowledge in given scenarios. The primary difference between the 
two lies in which way of knowing is dominant and which tends to be conferred collective authority in society and its institutions. In contemporary "Western" culture and in the postcolonial world, context-independent ways of knowing are dominant. Among the Asháninka I studied, context-dependent ways of knowing prevail. Yet as hybrid, syncretic forms of knowledge shaped by colonial legacies, indigenous epistemologies resist the limitations of binary distinctions. Drawing upon examples from my fieldwork, I consider two cases of hybridity that I encountered-changing social roles and human rights discourse-as examples of ways indigenous epistemologies counter binary frameworks and the double binds they produce.

\section{Changing Social Roles}

The first key indicator of epistemic legitimacy I encountered among the Asháninka was social role. The social category "professional" was mentioned constantly and held particular significance. It was used to indicate that my knowledge on matters regarding education, health, and nutrition was legitimate, though I had no formal training as a teacher or health professional. My social role as a professional was also used to undermine the reliability of my knowledge when it came to agriculture and the land, topics that someone in that social role would likely know little about. Gender was another social indicator used to identify the kinds of knowledge a person should have. For women, this meant knowledge of cooking, cleaning, and caring for children. There was no expectation that men would know how to do these things, and when they claimed they could prepare food or care for children, this knowledge was seldom considered legitimate.

When there is relative equality between social roles and tasks are seen as equal in importance, using social role as an indicator of epistemic legitimacy results in relative epistemic equality. The knowledge of both professionals and non-professionals, both men and women, is granted equal importance. In general, in foraging societies where men hunt and fish and women gather fruit, cook, and care for children, both kinds of tasks are considered equally important. The knowledge associated with both roles is valued more or less equivalently.

On the other hand, when epistemology is tied to social role in an unequal society, epistemic inequality ensues. When one social role is privileged over another, one kind of knowledge is also privileged over another. In a context where the benchmark of success is often professional occupation and those who have white-collar jobs enjoy a significantly higher standard of living than their blue-collar, non-professional counterparts, the ways of knowing associated with professional social roles hold more clout than those linked to nonprofessional social roles. In the same way, a gender hierarchy that values the social role of men over the role of women indicates that, in general, the knowledge associated with men is considered more legitimate and valuable than the knowledge associated with women.

But changing social roles among indigenous peoples have given rise to processes of hybridization in both social role and epistemic legitimacy. Environmental changes like deforestation and climate change have caused foraging and agriculture to become less viable economic options for indigenous peoples. As they more often opt to travel to urban centers to study for a profession-and as more universities are constructed outside of urban centers near the regions where indigenous peoples are concentrated-the clear-cut, binary distinction between professional and nonprofessional has begun to change. Indigenous people may occupy professional roles and, at the same, cultivate fields that have been in their families for generations. The lines between categories have begun to blur, indicating hybridity. Accompanying this hybridization of social role is the hybridization of epistemology, since the category "professional" serves less and less as a clear-cut epistemic indicator.

The same process of hybridization has impacted gender roles as well. NGOs, churches, and society as a whole have all contributed to the diffusion of new ideas about gender. Some of these groups have reinforced the idea that gender equality is "ideology" and must be opposed, while others have advanced feminist ideas regarding a woman's role in society (Espinosa 2017). In the economic sphere, 
change has been stimulated by a lack of labor opportunities in and near indigenous communities. When men leave the community in search of wage labor and are absent for extended periods of time, women take on men's roles in addition to their own. Their responsibilities include performing agricultural duties and occasionally even hunting, meaning that the epistemic expectations associated with being women also change. As roles adapt and change, the boundaries between them become less clearly defined. Binary epistemic distinctions begin to lose weight.

The growth of tourism and the sale of handcrafted products have provided women with more economic control as well. Women are often responsible for bringing tourists into their communities, and they are the ones who sell the handicrafts they make. The Asháninka community where I conducted fieldwork was not officially open to tourists, but those considering the possibility of involving the community in tourism were women. As women take on new roles and gain new knowledge, hybridization occurs. Clear-cut classifications of identity and knowledge begin to unravel. While these changes pose challenges to indigenous peoples, who are forced to renegotiate social roles and cultural identity, they also create hybrid identities and epistemologies. These new forms of knowledge and identity challenge simplistic dichotomies and demonstrate indigenous agency.

\section{Human Rights Discourse}

A second case of hybridization, the use of human rights discourse by indigenous peoples, undermines the oppressive structures of dominant knowledge frameworks in a different way. While many cultures have some notion of the values that underlie human rights theory, the genealogical roots of contemporary human rights discourse lie in "Western" modernity. Manfred Nowak (2017) explains, "Although the values underlying human rights can be found in most religions, cultures, and philosophies, the very idea of human rights as legal claims of human beings against those who have the power, on the one hand, to violate such rights, and on the other hand, to respect, protect, and fulfill such rights, only developed during the age of Enlightenment" (7). As a product of
Enlightenment thought, contemporary human rights theory was built upon universal principles. The notion of human rights as universal standards that are true in every time and in every place, independent of ethnicity, gender, religion, or place of origin, comes from a system of ethics tied to universal law rather than situated values.

Yet in my interviews with the Asháninka, human rights discourse was often used to defend indigenous identity and interests. One of my interview questions presented a scenario in which someone believed a particular ethnic group was inferior to another and stated that the two groups should not have equal privileges. I asked what each interviewee thought of this opinion and then, if they believed it was wrong, how they knew. Interviewees consistently answered that the person's opinion was wrong because all ethnic groups have equal rights, which means one group cannot be denied the same rights that another group is granted. The notion of human rights was used to justify the equitable treatment of all ethnic groups.

Among indigenous peoples, human rights discourse is often used in this way to counter practices of exclusion and marginalization (Thornberry 2002). When indigenous peoples argue that they have a right to the land they have inhabited for centuries, that they deserve access to a quality education, or that they are entitled to self-government, they are appealing to a system of human rights that arose out of the context-independent ethics of the Enlightenment. By adopting human rights discourse, they employ hybrid epistemic thought and demonstrate indigenous agency.

From their location on the fringes of "Western" modernity, indigenous peoples thus critique it by its own standards. To the extent that the structures and practices set into motion by "Western" modernity violate indigenous rights, the human rights discourse indigenous peoples employ serves as a mirror held up against it to indicate that it has fallen short of its own moral aims. Hybridity in human rights ideology offers a powerful critique of "Western" structures, not because it lies outside of them, but because it indicates the places where they break down. 


\section{Conclusions}

The ways of knowing that I encountered among the Asháninka contribute to epistemic resistance. They undermine and challenge oppressive structures along with the epistemic scaffolding that sustains them. First, these epistemologies challenge the notion of knowledge as information that can be extracted and applied indiscriminately of context. Knowledge is recast as a way of orienting towards the world within a particular context. For the Asháninka, knowledge and its justifications are person- and place-related. People and places are important not only with respect to what knowledge is known, but also for how legitimacy is established. Ethically, this reveals the importance of social and environmental context for buen vivir, or sustainable well-being. We know and live well when our epistemologies connect us to our identities and surroundings instead of requiring us to abstract from them. The epistemologies of the Asháninka de-center context-independent epistemologies, which justify knowledge according to criteria that can be universalized, from the place they occupy at the forefront of rational thought.

Secondly, the epistemologies I encountered among the Asháninka demonstrate hybridity. Hybrid epistemologies indicate both continuity and change among indigenous peoples, preserving important values and, at the same time, expressing adaptation and agency in the face of social, cultural, and environmental transitions. They also provide a glimpse into what resistance looks like in double bind situations where any available option reinforces one's own oppression. In these situations, hybridity provides a "third way," enabling people to express agency by weaving a different path. When colonial legacies that designate "indigenous" as "irrational" lock indigenous peoples into a double bind scenario where they must choose between being rational and being indigenous, hybridity provides an alternative that enables them to act with agency. Through their use of hybrid epistemologies, indigenous peoples resist the binary models of knowledge and identity that have been created and sustained through structures of coloniality. 


\section{Acknowledgements}

Thank you first and foremost to the Asháninka people who welcomed me into your community. For three weeks, you shared with me both your stories and your everyday lives. I especially want to thank Lourdes for investing in me and in my research, and Angélica for welcoming me into your home and allowing me to learn alongside of you. Your courage, patience, and resilience are not forgotten. Thank you to Jenell Paris, research advisor and mentor, for the many hours you spent reading my writing and listening to my ideas. Thanks as well to Bernardo Michael, professor and mentor, for urging me to develop my academic voice. I am challenged by both of you to move towards new ways of knowing and being in the world. Thank you to Oscar Espinosa, Professor of Anthropology at the Pontificia Universidad Católica del Perú (PUCP), for help with my interview questions. Finally, to the Asháninka and other indigenous inhabitants of the Amazon, thank you for challenging our conception of what it means to know and to live well. Esto lo escribo por ustedes. 


\section{References}

Barsh, Russel L. 2001. "Who Steals Indigenous Knowledge?" Proceedings of the Annual Meeting (American Society of International Law)95: 153-61. http://www.jstor.org/ stable/25659474.

Bhabha, Homi. 1994. The Location of Culture. London: Routledge.

Carothers, Courtney, Mark Moritz, and Rebecca Zarger. 2014. "Introduction: Conceptual, Methodological, Practical, and Ethical Challenges in Studying and Applying Indigenous Knowledge." Ecology and Society 19 (4): 43. http://www.jstor.org/ stable/26269650.

Castro-Gómez, Santiago. 2015. Crítica de la razón latinoamericana. Bogotá: Editorial Pontificia Universidad Javeriana.

Chowdhury, Nupur. 2004. "Patents Bill: Protecting Indigenous Knowledge." Economic and Political Weekly39 (46/47): 4984-86. http://www.jstor.org/stable/4415797.

Colchester, Marcus, and Andrew Gray. 1997. "Foreword." In From Principles to Practice: Indigenous Peoples and Biodiversity Conservation in Latin America. Proceedings from the Pucallpa Conference, edited by Andrew Gray, Alejandro Parellada, and Hellen Newing, 10-17. Copenhagen: IWGIA.

Conklin, Beth A., and Laura R. Graham. 1995. "The Shifting Middle Ground: Amazonian Indians and Eco-Politics." American Anthropologist, New Series, 97 (4): 695-710. www.jstor.org/ stable/682591.

de Acosta, José. (1590) 2002. Natural and Moral History of the Indies. Translated by Frances Lopez-Morillas. Durham: Duke University Press.

de las Casas, Bartolomé. (1552) 1992. A Short Account of the Destruction of the Indies. Translated by Nigel Griffin. London: Penguin Classics.

Descola, Philippe. 2013. Beyond Nature and Culture. Chicago: University of Chicago Press.

Espinosa, Oscar. 2017. "Gender and Political Leadership: Indigenous Women Organizations in the Peruvian Amazon Region." In Creating Dialogues: Indigenous Perceptions and Changing Forms of Leadership in Amazonia, edited by Hanne Veber and Pirjo Kristiina Virtanen, 215-238. Boulder: University of Colorado Press. 
Fanon, Franz. 1967. Black Skin, White Masks. New York: Grove Press.

Gadgil, Madhav, Fikret Berkes, and Carl Folke. 1993. "Indigenous Knowledge for Biodiversity Conservation." Ambio 22 (2/3): 151-56. http://www.jstor.org/stable/4314060.

García Canclini, Nestor. 1995. Hybrid Cultures: Strategies for Entering and Leaving Modernity. Minneapolis: University of Minnesota Press.

Grosfoguel, Ramón. 2011. “Decolonizing Post-Colonial Studies and Paradigms of Political-Economy: Transmodernity, Decolonial Thinking, and Global Coloniality." Transmodernity: Journal of Peripheral Cultural Production of the Luso-Hispanic World 1 (1).

Leach, Edmund R. 1961. Rethinking Anthropology. London: Athlone Press.

"Líder indígena amenazado por narcotraficantes pidió garantías para su vida." 2019. E/ Comercio, September 26, 2019. https:// elcomercio.pe/peru/lider-indigena-amenazado-pornarcotraficantes-pidio-garantias-para-su-vida-noticia/.

Mbembe, Achille. 2017. Critique of Black Reason. Durham: Duke University Press.

McClellan, Catharine. 1987. Part of the Land, Part of the Water: A History of the Yukon Indians. Vancouver; Toronto: Douglas \& McIntyre.

Mcgovern, Seana. 2000. "Reclaiming Education: Knowledge Practices and Indigenous Communities." Comparative Education Review 44 (4): 523-529. doi:10.1086/447633.

Medina, José. 2012. The Epistemology of Resistance: Gender and Racial Oppression, Epistemic Injustice, and the Social Imagination. Oxford: Oxford University Press.

Mishra, Tapan K. 1998. "Users Become Managers: Indigenous Knowledge and Modern Forestry." Economic and Political Weekly 33 (6): 262-63. http://www.jstor.org/stable/4406372.

Moore, Sally F. 1987. "Explaining the Present: Theoretical Dilemmas in Processual Ethnography." American Ethnologist 14 (4): 727-736. http://www.jstor.org/stable/645323.

Nadasdy, Paul. 1999. "The Politics of TEK: Power and the 'Integration' of Knowledge." Arctic Anthropology 36 (1/2): 1-18. www.jstor.org/ stable/40316502. 
Norchi, Charles H. 2000. "Indigenous Knowledge as Intellectual Property." Policy Sciences 33 (3/4): 387-98. http://www.jstor.org/ stable/4532511.

Nowak, Manfred. 2017. Human Rights or Global Capitalism: The Limits of Privatization. Philadelphia: University of Pennsylvania Press. www.jstor.org/stable/j.ctv2t4djs.

Orozco, David, and Latha Poonamallee. 2014. "The Role of Ethics in the Commercialization of Indigenous Knowledge." Journal of Business Ethics 119 (2): 275-86. http://www.jstor.org/ stable/42921290.

Pimenta, José. 2007. "Indigenismo e ambientalismo na Amazônia ocidental: A propósito dos Ashaninka do rio Amônia." Revista De Antropologia 50 (2): 633-81. www.jstor.org/stable/41616693.

“¿Quién es CARE?" n.d. Accessed January 25, 2020. https:// careashaninka.org/portada/.

Rojas Zolezzi, Enrique. 2014. El morral del colibrí: Mitología, chamanismo y ecología simbólica entre los asháninka del Oriente peruano. Lima: Editorial Horizonte.

Sahai, Suman. 1996. "Importance of Indigenous Knowledge in IPR System." Economic and Political Weekly 31 (47): 3043-45. http:// www.jstor.org/stable/4404790.

La Serna Salcedo, Juan Carlos. 2010. “Viviendo con el diablo en casa. La enfermedad, hechicería infantil y violencia entre los asháninka desde la perspectiva misionera adventista." Bulletin de l'Institut Français d'Études Andines 40 (1): 81-121.

Simpson, Leanne R. 2004. "Anticolonial Strategies for the Recovery and Maintenance of Indigenous Knowledge." American Indian Quarterly 28 (3/4): 373-84. http://www.jstor.org/stable/4138923.

Sylvester, Olivia, Alí García Segura, and lain J. Davidson-Hunt. 2016. "The Protection of Forest Biodiversity Can Conflict with Food Access for Indigenous People." Conservation \& Society 14 (3): 279290. www.jstor.org/stable/26393249.

Thornberry, Patrick. 2002. Indigenous Peoples and Human Rights. Manchester: University of Manchester Press. 
Viveiros de Castro, Eduardo. 2005. "Perspectivism and Multinaturalism in Indigenous America." In The Land Within: Indigenous Territory and Perception of the Environment, edited by Alexandre Surrallés and Pedro García Hierro, 36-75. Copenhagen: IWGIA.

Wilson, Waziyatawin A. 2004. "Introduction: Indigenous Knowledge Recovery Is Indigenous Empowerment." American Indian Quarterly28 (3/4): 359-72. http://www.jstor.org/stable/4138922.

Wohling, Marc. 2009. "The Problem of Scale in Indigenous Knowledge: A Perspective from Northern Australia." Ecology and Society 14 (1): 1. http://www.jstor.org/stable/26268043.

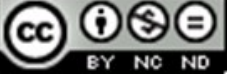

This work is licensed under a Creative Commons

Attribution-NonCommercialNoDerivatives

4.0 International License. 